\title{
Audit Sistem Informasi Menggunakan Frame- work COBIT 4.1 Domain Acquire and Implemen- tasi (AI) (Studi Kasus : Dinas Komunikasi dan Informatika Kota Malang)
}

\author{
Pandu Herlambang, Ilyas Nuryasin, Wildan Suharso \\ ${ }^{1,2,3}$ Universitas Muhammadiyah Malang \\ e-mail: *panduherlambang10@gmail.com
}

\begin{abstract}
Abstrak - Teknologi Informasi dan Sistem Informasi memiliki peranan yang begitu penting bagi setiap Instansi atau perusahaan yang memanfaatkan teknologi Informasi pada kegiatan bisnis, serta juga sebagai faktor dalam mencapai tujuan dari Instansi atau perusahaan tersebut. Pengukuran tingkat kematangan ini proses audit sistem informasi ini dilakukan dengan menggunakan COBIT 4.1 proses TI kemudian dipetakan COBIT Maturity Model. Hasil penelitian kemudian dipadukan unutk mendapatkan tingkat kematangan dari proses TI.
\end{abstract}

Kata Kunci: Teknologi Informasi, COBIT 4.1,Maturity Model

Abstract-Information Technology and Information Systems has a role that is so important for every agency or company that utilizes information technology on business activities, as well as a factor in achieving the goals of the agency or company.Measurement of the maturity level of this information system audit process is done by using COBIT 4.1 IT process and then mapped COBIT Maturity Model. The results are then combined to get the maturity level of the IT process.

Index Terms : Information Technology, COBIT 4.1, Maturity Model

\section{Pendahuluan}

Perkembangan dari teknologi informasi (TI) dan komunikasi kini semakin pesat diberbagai bidang. Hal ini juga dapat dilihat dengan adanya kebutuhan suatu perusahaan akan penerapan TI yang semakin meningkat guna untuk menunjang keberhasilan aktivitas dari bisnis dan meningkatkan kemampuan dalam kinerja. [1] Penggunaan dan pemanfaatan TI sebaiknya berfungsi dalam sebuah penyediaan dan orientasi layanan sehingga perusahaan atau sebuah instansi dapat menyelaraskan dengan adanya tujuan bisnis.

Tata Kelola TI adalah satu kesatuan dari konsep dasar Corporate Governence melalui peningkatan dari efiseiensi dan efektivitas dalam proses Instansi yang selalu berhubungan dengan TI.[3] Tata kelola TI menyediakan sebuah struktur yang menghubungkan proses TI, sumber daya TI dan juga informasi yang baik, benar, transparan sesuai tuntuan publik dan sesuai standar teknologi Informasi. [2] Salah satu isu yang sering marak saat ini berkenaan dengan adanya penggunaan TI adalah banyak organisasi sudah menggunakan TI tetapi belum sadar dengan adanya tata kelola TI yang sesuai standar untuk yang lebih optimal dan 
meningkatkan hasil, sekaligus dalam mengelolanya agar lebih baik untuk menghasilkan tujuan tersebut.

Audit Sistem informasi adalah sebuah bentuk pengawasan atau pengendalian dari infrastruktur TI secara keseluruhan. Audit Sistem informasi berjalan bersama dengan adanya audit internal dan audit finansial, atau suatu kegiatan dari evaluasi dan pengawasan yang sejenisnya. [9] Mulanya ini dikenal dengan audit peroses data elektronik dan untuk saat ini audit teknologi informasi umumnya adalah proses evaluasi dan pengumpulan dari semua kegiatan sistem informasi dalam perusahaan atau instansi.

Sistem infomasi yang digunakan atau saat ini berjalan di Dinas KOMINFO Kota Malang adalah Surat Digital sistem ini berfungsi sebagai sistem informasi untuk melihat surat secara digital yang dapat dilihat setiap dinas yang ada di Kota Malang.

Mengingat TI yang ada di Dinas KOMINFO penting dan membutuhkan sebuah investasi yang cukup besar dalam pengadaanya jadi perlu adanya suatu pengukuran pengendalian TI yang dilakukan. Pengelolaan pengendalian TI yang baik dari Dinas Komunikasi dan Informatika ini dapat juga bermanfaat dalam upaya peningkatan kinerja dari Instansi. Pengelolaan dalam pengendalian TI di Dinas tersebut perlu adanya pengukuran dari perencanaan teknologi Informasi yang sudah ada, pengimplementasian dan penyampaian sampai hasil dan dengan evaluasi atas TI.

Salah satu Kerangka atau Framework yang digunakan untuk mengetahui kinerja TI di Diskominfo adalah menggunakan kerangka Control Objective For Information and Related Technology (COBIT) 4.1 yang dikembangkan oleh IT Governance Institute (ITGI) [3]. Kerangka yang digunakan adalah 2 domain yaitu domain Plan dan Organise (PO) yang akan memberikan sebuah panduan dan arahan yang akan dilakukan untuk memberikan suatu solusi layanan dan domain Ac- quire dan Implement (AI) yang akan menyediakan dan merubahnya untuk menjadi sebuah layanan yang lebih baik. [4]

Melihat manfaat dari penerapan TI ini untuk terciptanya suatu tata kelola dan Sistem informasi yang sesuai standar maka akan dilakukan sebuah evaluasi pada Pemerintah kota Khususnya Dinas KOMINFO Kota Malang yang menggunakan COBIT 4.1 pada sub-domain yang sesuai dengan permasalahan dan kebutuhan Dinas KOMINFO Kota Malang. Hasil dari pengukuran ini adalah gambaran hasil tata Kelola TI dan Sistem Informasi saat ini dan hasil rekomendasi yang akan menjadi acuan perbaikan ke depannya sehingga pada Dinas KOMINFO Kota Malang menjadi lebih terukur dan lebih baik.

\section{Metodologi Penelitian}

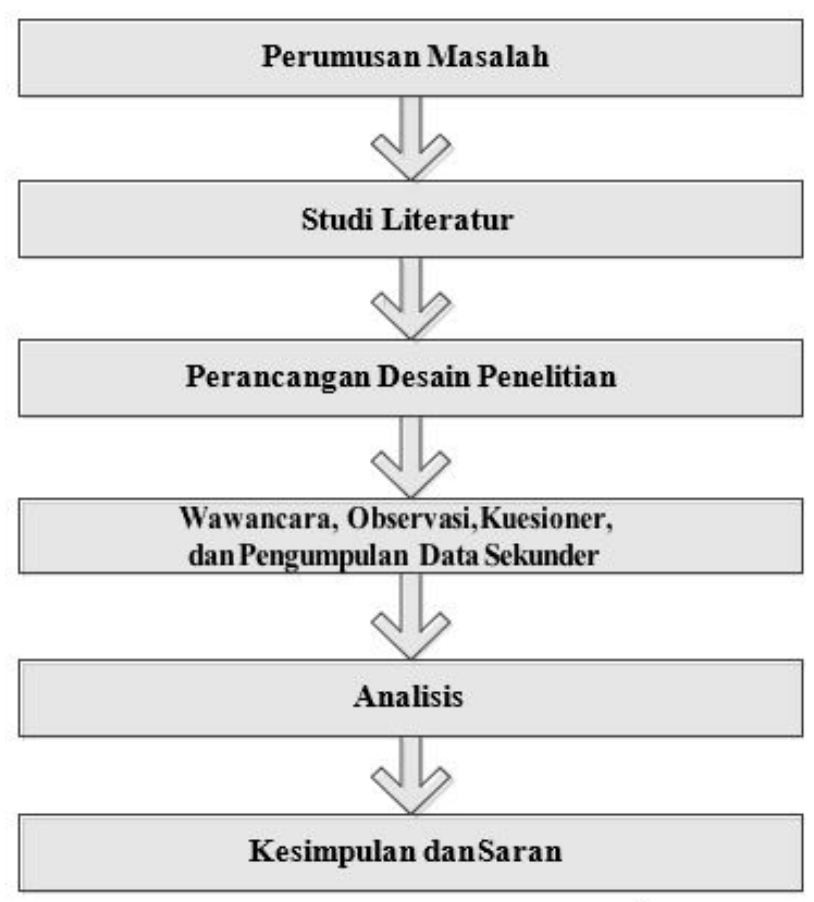

\subsection{Tahap Perumusan Masalah}

Yang dimaksud adalah dengan mengidentifikasi sebuah masalah ialah peneliti tahapan pertama dalam melakukan penelitian, yaitu merumuskan susatu masalah yang akan diteliti. Tahap adalah tahap yang paling utama dalam penelitian, karena jalannya penelitian ini akan dituntun dari 
perumusan masalah tersebut.[2]

\subsection{Tahap Studi Literatur}

Pada tahapan ini yaitu peneliti melakukan sebuah kajian pustaka, yaitu membaca atau mempelajari[3] dari buku-buku dan referensi atau hasil dari penelitian sejenis sebelumnya yang pernah ada atau dilakukan oleh peneliti yang lain.

\subsection{Tahap Desain Penelitian}

Desain penelitian ini khususnya adalah dalam penelitian yang menggunakan metode pendekatan kuantitatif merupakan alat untuk penelitian ini dimana seorang peneliti bergantung dalam menentukan tidak atau berhasilnya dari suatu penelitian yang sedang dilakukan.[4]

\subsection{Tahap Wawancara dan Observasi}

Wawancara dilakukan untuk mendapatkan data dengan cara lisan dari pihak-pihak terkait (stakeholder).[3] Wawancara yang dilakukan tersebut disimpan dalam sebuah rekaman untuk selanjutnya disusun secara disusun dalam bentuk dokumen sebagai hasil analisa. Observasi merupakan teknik yang digunakan peneliti untuk mendapatkan sebuah informasi yang dilakukan yaitu dengan cara pengamatan secara langsung terhadap objek yang diteliti sehingga dapat diperoleh kenyataan yang terjadi di lapangan.

\subsection{Tahap Analisis}

Analisis ini yaitu melakukan perhitungan data dan melakukan analisis yang sudah didapat kan dan di sesuaikan dengan metode COBIT 4.1 yang digunakan.

\subsection{Tahap Kesimpulan dan Saran}

Tahap terakhir dalam penelitian ini ialah membuat kesimpulan dan saran. Penelitian dapat ditarik menjadi kesimpulan dan saran dari peneliti dengan menganalisis pelaksanaan dan proses penelitian baik dari persiapan sebelum melakukan penelitian, pada saat melakukan penelitian maupun setelah melakukan sebuah penelitian. Hasil penelitian ini tergantung pada kemampuan dari peneliti untuk menafsirkan hasil secara logis dan data yang telah disusun dan secara sistematis menjadi sebuah ikatan pengertian untuk sebab-akibat obyek penelitian ini. Isi kesimpulan dari penelitian harus sesuai dan berdasarkan data keluaran yang diambil dari hasil proses penelitian yang telah dilakukan, [9]

\section{Hasil dan Pembahasan}

Tujuan dari penelitian ini adalah ini untuk terciptanya suatu tata kelola dan Sistem informasi yang sesuai standar maka akan dilakukan sebuah evaluasi pada Pemerintah kota Khususnya Dinas KOMINFO Kota Malang yang menggunakan COBIT 4.1 pada sub-domain yang sesuai dengan permasalahan dan kebutuhan Dinas KOMINFO Kota Malang. Hasil dari pengukuran ini adalah gambaran hasil tata Kelola TI dan Sistem Informasi saat ini dan hasil rekomendasi yang akan menjadi acuan perbaikan ke depannya sehingga pada Dinas KOMINFO Kota Malang menjadi lebih terukur dan lebih baik.

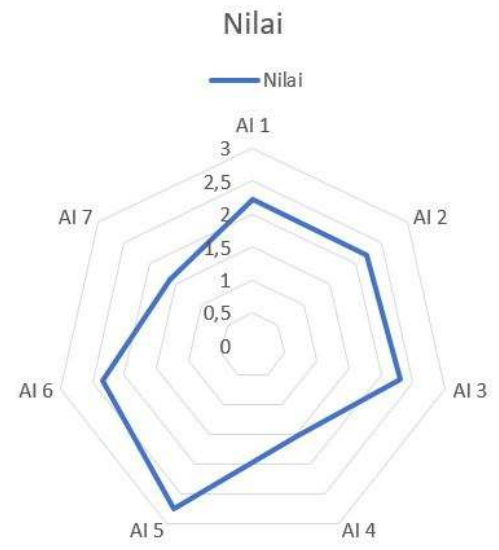

Gambar 1 Chart Domain AI

Menurut hasil yang sudah didapatkan yaitu kematangan dari domain AI pada Sistem Informasi dan tata kelola Teknologi Informasi Dinas Komunikasi dan Informatika Kota Malang yaitu 14.98 yang totalnya dan akan dibagi dari banyaknya sub domain yanga da di domain AI yaitu hasilnya 2.14 yang berarti tingkat kematangan pad atingkat 2 (repeatable but intuitive) tingkat ini sudah mengalami perkembangan, sudah ada prosedur untuk menjalankan sebuah proses didefenisikan, tetapi belum ada pelatihan formal dan prosedure komunikasi yang standar. 
Tabel 1 Hasil Maturity Model Domain AI (Acquire and Implement)

\begin{tabular}{|c|c|c|c|}
\hline \multicolumn{4}{|c|}{ COBIT 4.1 MATURITY MODEL } \\
\hline \multicolumn{2}{|c|}{ Domain } & \multicolumn{2}{|l|}{ Acquire and Implement (AI) } \\
\hline No. & $\begin{array}{l}\text { Kode } \\
\text { Proses }\end{array}$ & Proses TI & Nilai \\
\hline 11 & AI1 & Identify Automated Solution & 2,22 \\
\hline 12 & AI2 & Acquire and Maintain Application Software & 2,22 \\
\hline 13 & $\mathrm{AI} 3$ & Acquire and Maintain Technology Infrastructure & 2,31 \\
\hline 14 & AI4 & Enable Operation and Use & 1,53 \\
\hline 15 & AI5 & Procure IT Resources & 2,75 \\
\hline 16 & AI6 & Manage Changes & 2,35 \\
\hline 17 & AI7 & Install and Accredit Solutions and Changes & 1,60 \\
\hline & & Nilai Total & 14.98 \\
\hline \multicolumn{3}{|c|}{ Nilai kematangan Domain Acquire and Implement (AI) } & 2.14 \\
\hline
\end{tabular}

\section{Kesimpulan dan Saran}

COBIT 4.1 merupakan metode untuk melakukan pengukuran untuk standar IT dan COBIT 4.1 standar IT yang paling banyak digunakan dalam melakukan pengukuran dan Pengukuran tingkat kematangan proses tata kelola teknologi informasi dan Sistem Informasi dengan COBIT 4.1 maturity model pada Dinas Komunikasi dan Informatika Kota Malang memiliki ruang lingkup tujuan bisnis (Business Goals) sebanyak 13 (tiga belas), tujuan TI (IT Goals) sebanyak 23 (dua puluh tiga ) dan total proses TI (IT Process) sebanyak 36 (tuga puluh enam) proses.

\section{REFERENSI}

[1] Awalludiyah Ambarwati, Ariinta Deraya Ratulangi, "Evaluation of information technology implementation in business goal (improve and maintain business process functionality) at economic development group of East Java representative office", Sustainable Information Engineering and Technology (SIET) 2017 International Conference on, pp. 68-73, 2017.

[2] Ibrahim, lela NurpulaelaEvaluation of IT governance to support IT operation excellent based on COBIT 4.1 at the PT Timah Tbk (2016).

[3] Sandy, Vedyanto, i=I Dewi Ayu Eka Yuliani Maturity levels of academic information services of higher education using IT governance (2017)

[4] Noor Azizah (2017) Audit Sistem Informasi Menggunakan Framework Cobit 4.1 pada E-Learning Unisnu Jepara : Jepara : Jurnal SIMETRIS, Vol 8 No 1 April 2017 ISSN: 2252-4983.

[5] Johanes Fernandes Andry, (2016) Audit Tata kelola TI Menggunakan Kerangka Kerja Cobit Pada Domain DS dan ME di Perusahaan Kreavi Informatika Solusindo.Jakarta Utara : Seminar Nasional Teknologi Informasi dan Komunikasi (SENTIKA 2016)

[6] Inayatul Maghfiroh, Murahartawaty, dan Rahmat Mulyana. (2016) Analisis dan Perancangan Tata Kelola TI Menggunakan COBIT 4.1Domain Deliver dan Support DS PT XYZ . Bandung : Jurnal Sistem Informasi (Journal of Information Systems). 1/12, 50-55

[7] RENDRA NASRUL RIFAI, WASILAH (2015) Penggunaan metode Cobit Framework 4.1 dalam Mengaudit Sistem Informasi Akademik (Siakad) pada lain Raden Intan Lampung . Lampung : Jurnal TIM Darmajaya Vol. 01 No. 01 Mei 2015 ISSN: 2442-5567|E-ISSN: 2443-289X.

[8] I Putu Ade Ambara Putra, I Made Sukarsa, I Putu Agung Bayupati (2015) Audit Ti Kinerja Manajemen Pt. X Dengan Frame Work Cobit 4.1 . Lontar Komputer VOL.6 , NO.1, APRIL 2015 ISSN: 2088-1541.

[9] Wella, Johan Setiawan (2015) Audit Sistem Informasi menggunakan Cobit 4.1 pada PT.Erajaya Swasembada, Tbk. Tangerang Indonesia : ISSN 2085-4579

[10] E, Saputra, "Analisis Tata Kelola TI Dengan Menggunakan Metode Cobit 4.1 (Studi Kasus: BPR Danagung Bakti Yogyakarta)," Magister Teknik Informatika, Universitas Atma Jaya Yogyakarta, Yogyakarta, 2015 